Izvirni znanstveni članek/Original scientific article

\title{
Obvladovanje dejavnikov tveganja za nastanek srčno-žilnih bolezni v referenčni ambulanti družinske medicine
}

\author{
Managing risk factors for cardiovascular diseases in a reference family medicine clinic
}

\author{
Alenka Terbovc, Boštjan Gomišček
}

Ključne besede: diplomirana
medicinska sestra; kakovost;
kazalniki
Key words: registered nurse,
quality, quality indicators
Alenka Terbovc, dipl. m. s.,
mag. zdr. - soc. manag.;
Osnovno zdravstvo Gorenjske,
OE ZD Kranj, Gosposvetska 10,
Kranj, Slovenija
Kontaktni e-naslov/
Correspondence e-mail:
alenka.terbovc77@gmail.com
prof. dr. Boštjan Gomišček,
univ. dipl. inž. el.; University
of Wollongong in Dubai,
Faculty of Business, Block 15,
Knowledge ark, PO Box 20183,
Dubai, United Arab Emirates

\section{IZVLEČEK}

Uvod: Model referenčnih ambulant družinske medicine prinaša spremembe v obravnavi pacientov. Namen raziskave je bil preučiti dejavnike tveganja, ki prispevajo $\mathrm{k}$ zmanjšanju nastanka srčno-žilnih bolezni $\mathrm{z}$ nefarmakološkimi ukrepi pri pacientih v referenčni ambulanti družinske medicine.

Metode: Narejena je bila retrogradna raziskava podatkov pacientov, ki so bili obravnavani v referenčnih ambulantah za srčno-žilno ogroženost. Naključni raziskovalni vzorec je obsegal 128 pacientov, ki so v obdobju od 1. maja do 25. avgusta $2014 \mathrm{v}$ referenčni ambulanti družinske medicine opravili presejalni in kontrolni pregled. Podatki so bili analizirani z opisno statistiko in hi-kvadrat testom.

Rezultati: Pri obravnavanih pacientih so bili pri kontrolnem pregledu v primerjavi s presejalnim ugotovljeni višji deleži urejenih preiskovanih parametrov, in sicer pri krvnem tlaku $(41,6 \%)$, holesterolu $(45,5 \%)$ in krvnem sladkorju (53,3 \%), zmanjšal se je tudi delež kadilcev, in sicer za $4 \%$. Visoka srčno-žilna ogroženost (20-40 \%) se je pri kontrolni meritvi znižala na $28 \%$, zelo visoka na 6,6 \%. Po obravnavi v ambulanti se je telesna aktivnost, izvajana od 2- do 4-krat na teden, povečala na $54,3 \%$ oz. telesna aktivnost, izvajana 5-krat na teden, na $19,4 \%$. Statistično značilne razlike so se pokazale pri krvnem tlaku $\left(\chi^{2}=8,780, p=0,003\right)$ in holesterolu $\left(\chi^{2}=4,781, p=0,029\right)$.

Diskusija in zaključek: Po ambulantni obravnavi se je pri pacientih pomembno izboljšala vrednost nekaterih dejavnikov tveganja, kar je moč pripisati kakovostni obravnavi, ki jo omogoča model referenčnih ambulant, in vlogi diplomirane medicinske sestre $\mathrm{v}$ tem modelu.

\footnotetext{
ABSTRACT

Introduction: The model of reference family medicine clinics is introducing changes to the treatment of patients at the primary health level. The purpose of the study was to explore the risk factors that contribute to reducing the occurrence of cardiovascular disease using non-pharmacological approaches in patients who are treated in a reference medicine family clinic.

Methods: A retrograde survey was carried out on the data of the patients, who were treated in reference clinics for cardiovascular risk. The random study sample covered 128 patients, who passed the screening tests and control measurements in a reference medicine family clinic in the period from 1 May to 25 August 2014. Data were analysed using descriptive statistics and chi-square test.

Results: Screening tests revealed a higher share of patients with acceptable measured parameters for blood pressure (41.6\%), cholesterol (45.5\%) and blood sugar (53.3\%) while the percentage of smokers decreased by $4 \%$. High cardiovascular risk (20-40\%) has reduced to $28.0 \%$, whereas extremely high cardiovascular risk decreased to $6.6 \%$. After the treatment in the clinic, the percentage of people performing physical activity 2-4 times per week increased to $54.3 \%$ while $19.4 \%$ of respondents reported physical activity 5 times per week. Statistically significant differences were demonstrated for blood pressure $\left(\chi^{2}=8.780, p=0.003\right)$ and cholesterol $\left(\chi^{2}=4.781, p=0.029\right)$.

Discussion and conclusions: Patients have significantly improved risk factors due to quality treatment that is
}

Članek je nastal na osnovi magistrskega dela Alenke Terbovc Obvladovanje dejavnikov tveganja za nastanek srčno-žilnih bolezni pri pacientih, vodenih $v$ referenčni ambulanti družinske medicine - vloga diplomirane medicinske sestre (2015).

Prejeto/Received: 2. 6. 2016

Sprejeto/Accepted: 31. 1. 2017 


\section{Uvod}

Bolezni srca in ožilja so najbolj razširjene kronične nenalezljive bolezni. V razvitih državah so na prvem mestu najpogostejših vzrokov umrljivosti, medtem ko v manj razvitih državah pričakujejo, da bodo to mesto zasedle v nekaj letih. Vsako leto po svetu zaradi njih umre 17,5 milijona ljudi, v Evropi, kjer predstavljajo vzrok za več kot polovico vseh smrti, več kot 1,9 milijona. V Sloveniji zaradi bolezni srca in ožilja zboli povprečno 20.000 ljudi na leto, umre pa jih okoli 9.000 . Tako bolezni srca in ožilja povzročajo skoraj 40 $\%$ vseh smrti v Sloveniji, kar je več, kot jih umre zaradi rakavih bolezni skupaj (Šic, 2009).

Svetovna zdravstvena organizacija opozarja na skokovito naraščanje s starostjo in življenjskim slogom povezanih bolezni, ki vodijo v razvoj kroničnih bolezni, kot so sladkorna bolezen, srčno-žilne bolezni, rak in bolezni dihal (World Health Organization, 2008). Ne le, da se povečuje delež starejših, podaljšuje se tudi delovna doba, kar pomeni, da morajo delavci delati tudi s kronično boleznijo. Skrb prebivalcev za lastno zdravje postaja vse pomembnejša. Tako se vedno bolj priznava pomen ozaveščanja prebivalstva, saj le-to na različne načine pripomore $\mathrm{k}$ preprečevanju, pa tudi $\mathrm{k}$ obvladovanju in rehabilitaciji kroničnih bolezni (Clark, 2010; Štemberger Kolnik \& Klemenc, et al., 2010).

Bolezni srca in ožilja so v Sloveniji glavni vzrok obolevnosti in smrtnosti, izostajanja $\mathrm{z}$ dela in invalidnosti (Cipot Prinčič, 2005). Kot pomemben vzrok smrti se pričnejo pojavljati že po 45. letu starosti (Govc Eržen, 2004). Z aktivnim presejanjem za posamezne vrste kroničnih bolezni in $\mathrm{z}$ odkrivanjem dejavnikov tveganja za nastanek srčno-žilnih bolezni $\mathrm{s}$ pomočjo vprašalnikov se $\mathrm{z}$ uvedbo referenčnih ambulant družinske medicine razširjajo dejavnosti ambulante družinske medicine (Bizjak, 2013).

Referenčna ambulanta družinske medicine (RADM) pomeni napredek v timski obravnavi in hkrati tudi povečano dostopnost zdravstvenih storitev prebivalcem (Ministrstvo za zdravje Republike Slovenije, 2011). Delo diplomirane medicinske sestre v RADM temelji na učenju pacienta o zdravem življenjskem slogu in ohranjanju zdravja, kar $\mathrm{v}$ današnjem času od nje zahteva veliko sposobnost svetovanja in motiviranja pacienta, ki želi svoj življenjski slog spreminjati na bolje (Štemberger Kolnik \& Klemenc, 2010).

Dostopna literatura o delu diplomiranih medicinskih sester na tem področju $\mathrm{v}$ tujem prostoru dokazuje, da so medicinske sestre že bile prepoznane kot strokovnjakinje na področju obvladovanja kroničnih nenalezljivih bolezni. V primerjalni raziskavi o delu zdravnika in delu diplomirane medicinske sestre pri prvem stiku in svetovanju pacientu Paniagua (2011) ugotavlja, da so se pacienti $\mathrm{v}$ vseh stopnjah prvega srečanja in posvetovanja na diplomirano medicinsko sestro pozitivno odzvali. Pacienti so bolj kot pri zdravniku sodelovali $\mathrm{v}$ pogovoru in izražali svoja mnenja, pri sami obravnavi so bili tudi bolj sproščeni (Paniagua, 2011). V raziskavi, ki jo je izvedla Organizacija za gospodarsko sodelovanje in razvoj (Organisation for Economic Co-operation and Development - OECD), ugotavljajo, da imajo pri izboljšanju zagotavljanja zdravstvenih storitev ključno vlogo prav medicinske sestre (Delamaire \& Lafortune, 2010).

\section{Namen in cilji}

Namen raziskave je bil ugotoviti uspešnost diplomirane medicinske sestre pri učenju in motiviranju pacientov za spremembo življenjskega sloga $\mathrm{Z}$ nefarmakološkimi ukrepi in posledično njeno uspešnost pri zmanjševanju dejavnikov tveganja za nastanek srčno-žilnih bolezni. Želeli smo preučiti vlogo diplomirane medicinske sestre in RADM pri zdravju ljudi ter tudi potrebo po sodelovanju pacienta pri izvajanju kakovostne zdravstvene obravnave. Cilji raziskave so bili oceniti vlogo diplomirane medicinske sestre pri zmanjšanju dejavnikov tveganja pri pacientih $\mathrm{z}$ visokim tveganjem za nastanek srčnožilnih obolenj, izmeriti doseganje ciljnih vrednosti in ugotoviti razlike $\mathrm{v}$ ciljnih vrednostih po posameznih dejavnikih tveganja oz. izbranih parametrih. Osnovno raziskovalno vprašanje je bilo povezano $\mathrm{z}$ razlikami glede dejavnikov tveganja pri različnih skupinah pacientov, vključenih $\mathrm{v}$ obravnavo $\mathrm{v}$ referenčni ambulanti družinske medicine. S tem namenom smo preverjali naslednji hipotezi:

H1: Pri zmanjševanju dejavnikov tveganja za nastanek srčno-žilnih bolezni obstaja statistično značilna razlika med presejalnim in kontrolnim pregledom.

H2: Pri zmanjševanju dejavnikov tveganja za nastanek srčno-žilnih bolezni obstaja statistično značilna razlika med ženskami in moškimi.

\section{Metode}

Raziskava je neeksperimentalne opisne kvantitativne zasnove in je potekala na osnovi zbiranja podatkov $s$ prospektivno metodo dela. Želene podatke smo pridobili iz medicinske dokumentacije in dokumentacije, ki jo vodi diplomirana medicinska sestra v RADM.

\section{Opis instrumenta}

Za namen zbiranja podatkov smo izdelali obrazec, kamor smo vpisovali podatke iz dokumentacije pacientov, ki so $\mathrm{v}$ RADM opravili presejalni in kontrolni pregled. Obrazec je zajemal tudi splošne podatke o pacientih, kot sta spol in starost, ter vrednosti naslednjih spremenljivk (dejavnikov tveganja): krvni tlak, holesterol, krvni sladkor, telesna teža, kajenje, telesna dejavnost, srčno-žilna ogroženost. 


\section{Opis vzorca}

V raziskavo je bilo vključenih osem RADM, ki so pred začetkom raziskave delovale najmanj eno leto. Raziskovalni vzorec je zajemal 64 žensk in 64 moških, ki so v RADM opravili presejalne in kontrolne obravnave. $\mathrm{V}$ vsaki od osmih RADM smo po vnaprej določenem ključu izbrali osem moških in osem žensk $\mathrm{z}$ opravljeno presejalno in kontrolno meritvijo. Preiskovanci so bili stari od 45 do 60 let, njihova povprečna starost je bila 50,1 leta.

\section{Opis poteka raziskave in obdelave podatkov}

Raziskava je potekala v Zdravstvenem domu Kranj od 1. maja 2014 do 25. avgusta 2014. Naključen vzorec smo izbrali tako, da smo vsaki od osmih ambulant naključno dodelili črke abecede. Črka je predstavljala začetno črko priimka, s katerimi smo izbrali osem moških in osem žensk, ki so opravili presejalni pregled in kontrolno meritev v RADM. Pri zbranih podatkih o dejavnikih tveganja smo upoštevali naslednje smernice mejnih referenčnih vrednosti: 1) krvni tlak - 140/90 $\mathrm{mmHg}$, 2) holesterol - 5,7 mmol/L, 3) krvni sladkor $6,0 \mathrm{mmol} / \mathrm{L}, 4)$ telesna teža - relativna masa nad $120 \%$ idealne telesne mase, 5) kajenje - ena cigareta dnevno ali več, 6) telesna dejavnost - kot dnevno aktivnost smo upoštevali 20-30 min gibalne aktivnosti, 7) srčnožilna ogroženost - stopnja verjetnosti za nastanek koronarnega dogodka $v 10$ letih, in sicer majhna: $<5 \%$, blaga: $5-10 \%$, zmerna: $10-20 \%$, visoka: $20-40 \%$ in zelo visoka: $>40 \%$. Za analizo zbranih podatkov smo uporabili osnovno opisno statistiko in hi-kvadrat test $\left(\chi^{2}\right)$. Statistična analiza je bila izvedena s programom SPSS verzija 20.0 (SPSS Inc., Chicago, IL, USA). Mejo statistične značilnosti je določala vrednost $\mathrm{p}<0,05$.

\section{Rezultati}

Rezultati raziskave, navedeni v Tabeli 1, prikazujejo, da je pri prvem presejalnem pregledu v RADM 68,8 $\%(n=88)$ preiskovancev imelo neurejen krvni tlak, $57,8 \%(n=74)$ neurejen holesterol in 57,8 \% $(n=74)$ neurejen krvni sladkor. Kadilcev je bilo $25 \%(n=32)$, visoka srčno-žilna ogroženost $(20-40 \%)$ je bila izmerjena pri 33,6 \% $(n=43)$ preiskovancev, zelo visoka srčno-žilna ogroženost pa pri $9,4 \%(n=12)$. Največji delež preiskovancev je navajal, da se gibljejo 2 - do 4-krat tedensko $(53,1 \%)(n=68)$ ali enkrat tedensko $(33,6 \%)(n=43)$.

Tabela 1: Primerjava med presejalnim pregledom in kontrolo $v$ RADM

Table 1: Comparison between the screening examination and control measurements in a RFMC

\begin{tabular}{|c|c|c|c|c|}
\hline $\begin{array}{l}\text { Opazovani parametri/ } \\
\text { Observed parameters }\end{array}$ & $\begin{array}{l}\text { Presejalni pregled/ } \\
\text { Screening examination } \\
n(\%)\end{array}$ & $\begin{array}{l}\text { Kontrolna meritev/ } \\
\text { Control measurement } \\
n(\%)\end{array}$ & $\chi^{2}$ & $p$ \\
\hline Krvni tlak & & & 10,091 & 0,001 \\
\hline Neurejen & $88(68,8)$ & $63(49,2)$ & & \\
\hline Urejen & $40(31,2)$ & $65(50,8)$ & & \\
\hline Holesterol & & & 2,649 & 0,104 \\
\hline Neurejen & $74(57,8)$ & $61(47,7)$ & & \\
\hline Urejen & $54(42,2)$ & $67(52,3)$ & & \\
\hline Krvni sladkor & & & 1,900 & 0,168 \\
\hline Neurejen & $74(57,8)$ & $63(49,2)$ & & \\
\hline Urejen & $54(42,2)$ & $65(50,8)$ & & \\
\hline Kajenje & & & 0,551 & 0,458 \\
\hline $\mathrm{Ne}$ & $96(75,0)$ & $101(78,9)$ & & \\
\hline $\mathrm{Da}$ & $32(25,0)$ & $27(21,1)$ & & \\
\hline Srčno-žilna ogroženost & & & 6,274 & 0,099 \\
\hline$<5 \%$ & $0(0,0)$ & $0(0,0)$ & & \\
\hline $5-10 \%$ & $25(19,5)$ & $30(23,4)$ & & \\
\hline $10-20 \%$ & $48(37,5)$ & $62(48,4)$ & & \\
\hline $20-40 \%$ & $43(33,6)$ & $29(22,7)$ & & \\
\hline$>40 \%$ & $12(9,4)$ & $7(5,5)$ & & \\
\hline Gibanje & & & 26,553 & 0,001 \\
\hline Brez & $12(9,4)$ & $4(3,1)$ & & \\
\hline 1-krat tedensko & $43(33,6)$ & $20(15,6)$ & & \\
\hline Od 2- do 4-krat tedensko & $68(53,1)$ & $79(61,7)$ & & \\
\hline 5-krat tedensko & $5(3,9)$ & $25(19,6)$ & & \\
\hline
\end{tabular}


Preiskovanci, obravnavani v RADM, so ob kontrolni meritvi dosegli statistično pomembne izboljšave pri dveh dejavnikih tveganja. Statistično pomembna razlika se je pokazala $\mathrm{v}$ deležu preiskovancev $\mathrm{z}$ urejenim krvnim tlakom (50,8 \%), le-ta je presegel delež tistih preiskovancev, ki so ob kontrolni meritvi še vedno imeli neurejen krvni tlak $(49,2 \%)\left(\chi^{2}=10,091, p<0,001\right)$. Zmanjšala se je tudi visoka ogroženost za srčno-žilna obolenja, in sicer se je delež preiskovancev z zelo visoko srčno-žilno ogroženostjo zmanjšal z 9,4 \% $(n=12)$ na 5,5 \% $(n=7)$. To potrdijo rezultati telesne aktivnosti, saj se je $\mathrm{v}$ raziskavi pokazala statistično pomembna razlika tako $\mathrm{v}$ deležu preiskovancev, ki se gibljejo od 2- do 4-krat tedensko, njihov delež se je povečal s $53,1 \%$ na $61,7 \%$, kot v deležu preiskovancev, ki se gibljejo 5-krat tedensko, delež le-teh se je povečal s 3,9\% na $19,6 \%\left(\chi^{2}=26,553, p<0,001\right)$.

Pri skupini preiskovancev, ki je bila obravnavana in vodena $\mathrm{v}$ RADM, rezultati raziskave pokažejo statistično pomembno razliko $\mathrm{v}$ nekaterih dejavnikih tveganja glede na presejalni pregled in kontrolno meritev. Hipoteza 1, ki pravi, da pri dejavnikih tveganja obstaja statistično pomembna razlika med presejalnim in kontrolnim pregledom, se tako delno potrdi.

$\mathrm{V}$ drugem delu raziskave smo se osredotočili predvsem na razlike med spoloma preiskovancev, obravnavanih v RADM (Tabela 2, Tabela 3). Pri prvem presejalnem pregledu rezultati raziskave kažejo, da je imelo sorazmerno visoko število preiskovancev $\mathrm{v}$ RADM neurejen krvni tlak, in sicer 71,9 \% $(n=46)$ moških in 65,6 \% $(n=42)$ žensk; neurejen holesterol je imelo $60,9 \%(n=39)$ moških in $54,7 \%(n=35)$ žensk, neurejen krvni sladkor je imelo 59,4 \% $(n=$ 38) moških in 56,3\% $(n=36)$ žensk. Kadilo je enako število žensk kot moških ( $n=16,25 \%)$.

Rezultati kažejo, da so tako moški kot ženske ob kontrolni meritvi dosegali enako dobre rezultate. Razlika se je pokazala le pri visoki srčno-žilni ogroženosti in zelo visoki srčno-žilni ogroženosti, ki se je pomembno znižala predvsem pri ženskah, čeprav razlika med presejalno in kontrolno meritvijo ni statistično pomembna. Ob kontrolni meritvi nobena preiskovanka ni bila zelo visoko ogrožena, delež žensk $\mathrm{z}$ visoko ogroženostjo za srčno-žilna obolenja pa se je zmanjšal s $25,0 \%$ na $18,8 \%(\chi 2=3,171, p=0,366)$ (Tabela 2). Pri moških je bil delež zmanjšanja srčnožilne ogroženosti nižji (Tabela 3).

Glede na hipotezo 2 smo ločeno raziskali presejalne in kontrolne meritve žensk in moških, obravnavanih v RADM. Rezultati, prikazani v Tabeli 2, kažejo, da so ženske pri kontrolni meritvi dosegle statistično pomembno razliko le pri enem dejavniku tveganja, saj se je delež aktivnega gibanja močno povečal pri

Tabela 2: Primerjava med presejalnim pregledom in kontrolno meritvijo za ženske v skupini RADM Table 2: Comparison between the screening examination and control measurements for females in a RFMC

\begin{tabular}{|c|c|c|c|c|}
\hline $\begin{array}{l}\text { Opazovani parametri/ } \\
\text { Observed parameters }\end{array}$ & $\begin{array}{l}\text { Presejalni pregled/ } \\
\text { Screening examination } \\
n=64(\%)\end{array}$ & $\begin{array}{l}\text { Kontrolna meritev/Control } \\
\text { measurement } \\
n=64(\%)\end{array}$ & $\chi^{2}$ & $p$ \\
\hline Krvni tlak & & & 2,073 & 0,150 \\
\hline Neurejen & $42(65,6)$ & $34(53,1)$ & & \\
\hline Urejen & $22(34,4)$ & $30(46,9)$ & & \\
\hline Holesterol & & & 1,125 & 0,289 \\
\hline Neurejen & $35(54,7)$ & $29(45,3)$ & & \\
\hline Urejen & $29(45,3)$ & $35(54,7)$ & & \\
\hline Krvni sladkor & & & 2,000 & 0,157 \\
\hline Neurejen & $36(56,3)$ & $28(43,7)$ & & \\
\hline Urejen & $28(43,7)$ & $36(56,3)$ & & \\
\hline Kajenje & & & 0,174 & 0,676 \\
\hline $\mathrm{Ne}$ & $48(75,0)$ & $50(78,1)$ & & \\
\hline $\mathrm{Da}$ & $16(25,0)$ & $14(21,9)$ & & \\
\hline Srčno-žilna ogroženost & & & 3,171 & 0,366 \\
\hline$<5 \%$ & $0(0,0)$ & $0(0,0)$ & & \\
\hline $5-10 \%$ & $19(29,7)$ & $24(37,4)$ & & \\
\hline $10-20 \%$ & $27(42,2)$ & $28(43,8)$ & & \\
\hline $20-40 \%$ & $16(25,0)$ & $12(18,8)$ & & \\
\hline$>40 \%$ & $2(3,1)$ & $0(0,0)$ & & \\
\hline Gibanje & & & 15,931 & 0,001 \\
\hline Brez & $7(10,9)$ & $2(3,1)$ & & \\
\hline 1-krat tedensko & $23(35,9)$ & $10(15,6)$ & & \\
\hline Od 2- do 4-krat tedensko & $32(50,0)$ & $40(62,5)$ & & \\
\hline 5-krat tedensko & $2(3,1)$ & $12(18,8)$ & & \\
\hline
\end{tabular}


Tabela 3: Primerjava med presejalnim pregledom in kontrolno meritvijo za moške v skupini RADM Table 3: Comparison between the screening examination and control measurements for males in a RFMC

\begin{tabular}{|c|c|c|c|c|}
\hline $\begin{array}{l}\text { Opazovani parametri/ } \\
\text { Observed parameters }\end{array}$ & $\begin{array}{l}\text { Presejalni pregled/ } \\
\text { Screening examination } \\
n=64(\%)\end{array}$ & $\begin{array}{l}\text { Kontrolna meritev/ } \\
\text { Control measurement } \\
n=64(\%)\end{array}$ & $x^{2}$ & $p$ \\
\hline Krvni tlak & & & 9,306 & 0,002 \\
\hline Neurejen & $46(71,9)$ & $29(45,3)$ & & \\
\hline Urejen & $18(28,1)$ & $35(54,7)$ & & \\
\hline Holesterol & & & 1,550 & 0,213 \\
\hline Neurejen & $39(60,9)$ & $32(50,0)$ & & \\
\hline Urejen & $25(39,1)$ & $32(50,0)$ & & \\
\hline Krvni sladkor & & & 0,287 & 0,592 \\
\hline Neurejen & $38(59,4)$ & $35(54,7)$ & & \\
\hline Urejen & $26(40,6)$ & $29(45,3)$ & & \\
\hline Kajenje & & & 0,401 & 0,526 \\
\hline $\mathrm{Ne}$ & $48(75,0)$ & $51(79,7)$ & & \\
\hline $\mathrm{Da}$ & $16(25,0)$ & $13(20,3)$ & & \\
\hline Srčno-žilna ogroženost & & & 5,875 & 0,118 \\
\hline$<5 \%$ & $0(0,0)$ & $0(0,0)$ & & \\
\hline $5-10 \%$ & $6(9,4)$ & $6(9,4)$ & & \\
\hline $10-20 \%$ & $21(32,8)$ & $34(53,1)$ & & \\
\hline $20-40 \%$ & $27(42,2)$ & $17(26,6)$ & & \\
\hline$>40 \%$ & $10(15,6)$ & $7(10,9)$ & & \\
\hline Gibanje & & & 10,989 & 0,012 \\
\hline Brez & $5(7,8)$ & $2(3,1)$ & & \\
\hline 1-krat tedensko & $20(31,3)$ & $10(15,6)$ & & \\
\hline Od 2- do 4-krat tedensko & $36(56,3)$ & $39(60,9)$ & & \\
\hline 5-krat tedensko & $3(4,6)$ & $13(20,4)$ & & \\
\hline
\end{tabular}

gibanju 5-krat tedensko, in sicer s 3,1\% $(n=2)$ na $18,8 \%(n=12)$. Rezultati raziskave kažejo, da je ob kontrolni meritvi le osem žensk uredilo krvni tlak, prav tako krvni sladkor, šest jih je uredilo celokupni holesterol, le dve sta prenehali kaditi. Deloma se je izboljšal odstotek visoke srčno-žilne ogroženosti in odstotek zelo visoke srčno-žilne ogroženosti, vendar le-ta že ob presejalnem pregledu ni predstavljal pomembnega deleža.

Nadalje $\mathrm{v}$ raziskavi ugotavljamo, da rezultati, prikazani v Tabeli 3, pri kontrolni meritvi moških $\mathrm{v}$ RADM glede na presejalni pregled kažejo statistično pomembno razliko pri urejenosti krvnega tlaka, in sicer se je delež preiskovancev $\mathrm{z}$ urejenim krvnim tlakom povečal z $28,1 \%$ na $54,7 \%(\chi 2=9,306, p=0,002)$. Povečal se je tudi delež telesno aktivnih moških (s $4,6 \%$ na $20,4 \%$ ), podatki glede gibanja so pokazali tudi statistično pomembno razliko $(\chi 2=10,989, p=$ 0,012 ). Glede na presejalni test je ob kontrolni meritvi dodatnih sedem moških imelo urejen celokupni holesterol in dodatni trije krvni sladkor. Trije moški so prenehali kaditi in trem je uspelo zelo visoko srčnožilno ogroženost znižati. Še vedno je ostal dokaj visok delež moških $\mathrm{z}$ visoko srčno-žilno ogroženostjo $(n=$ $17,26,6 \%$ ), a glede na podatke se je v primerjavi $\mathrm{s}$ presejalnim pregledom delež moških z majhno srčno- žilno ogroženostjo povečal, in sicer z $32,8 \%(n=32)$ na $53,1 \%(n=34)$.

Rezultati primerjave med spoloma kažejo, da so bile ženske, obravnavane v RADM, pri presejalnem pregledu manj ogrožene kot moški. Razlika je ostala tudi pri kontrolni meritvi. Pri vseh ostalih dejavnikih tveganja pri presejalnem pregledu razlik nismo ugotovili, prav tako se le-te niso pojavile ob kontrolnih meritvah. Ločena primerjava za moške in ženske je pokazala, da so moški izkazali celo nekoliko boljši napredek kot ženske. Hipoteza 2, ki pravi, da obstaja statistično značilna razlika med spoloma pri dejavnikih tveganja, se tako delno potrdi.

\section{Diskusija}

$\mathrm{V}$ raziskavi smo dokazali pomen dela diplomirane medicinske sestre pri učenju in motiviranju pacientov za spremembo življenjskega sloga z nefarmakološkimi ukrepi pri zmanjševanju dejavnikov tveganja za nastanek srčno-žilnih bolezni. Izvajanje preventivnih, t. i. presejalnih pregledov v RADM pacientu omogoča kakovostno zdravstveno obravnavo, ki vključuje zdravstveno vzgojo, odpravljanje ali zmanjševanje dejavnikov tveganja, poznavanje morebitnih bolezni, zdravljenje le-teh in njihovih zapletov. Diplomirana 
medicinska sestra ima znanje, odgovornost in določene kompetence, s katerimi pacienta vodi do zdravega načina življenja, do zmanjševanja dejavnikov tveganja za nastanek srčno-žilnih bolezni in do urejenega zdravstvenega stanja. Da ima potrebno strokovnost in znanje o zdravstvenih problemih, $\mathrm{v}$ izvedeni raziskavi potrjujeta tudi Pečelin in Sočan (2015), ki menita, da diplomirane medicinske sestre $\mathrm{v}$ referenčni ambulanti $\mathrm{z}$ dodatnimi izobraževanji pridobijo znanja iz komunikacije in sposobnosti svetovanja glede zdravega načina življenja, pri tem pa so tudi odgovorne, strokovne in natančne. Potrebo po dodatnem izobraževanju diplomiranih medicinskih sester v referenčni ambulanti v svoji raziskavi potrjujeta tudi Petek Šter in Šter (2014), ki ugotavljata, da je bila potreba po dodatnem izobraževanju pravilna, sajje delo specifično in zahteva posebna znanja. Diplomirana medicinska sestra je osredotočena na pacienta, izhaja iz njegovih potreb in vidika pacientovega vedenja ter prevzemanja pacientove odgovornosti za lastno zdravje (Collins, 2005). Redsell in Cheater (2008) sta pripravila pregled primerov dobrih praks z namenom, da ugotovita, ali diplomirana medicinska sestra lahko izvaja zdravniku enakovredno zdravstveno obravnavo pri prvem stiku s pacientom. V pregledu 11 poskusov in 23 opazovanj ugotavljata, da večja dostopnost do diplomirane medicinske sestre vodi $\mathrm{k}$ večjemu zadovoljstvu pacientov in višji kakovosti zdravstvene obravnave. Prav tako ugotavljata, da medicinske sestre izvedejo več preiskav in ponujajo daljša svetovanja. $\mathrm{V}$ naši raziskavi smo ugotovili, da $\mathrm{z}$ daljšim svetovanjem in vodenjem pacientov prihaja do pozitivnih rezultatov, kar so potrdili tudi drugi avtorji (Shum, et al., 2000, Venning, et al., 2000; Horrocks, et al., 2002).

Diplomirana medicinska sestra je v RADM s svojim delom in večkratnimi ambulantnimi kontrolami, pri katerih je paciente osveščala o zdravem načinu življenja in jih motivirala za spremembe prehranjevalnih in gibalnihnavad, pripomogla,dajeskupinapreiskovancev zmanjšala tveganje za nastanek srčno-žilnih bolezni, medtem ko so $\mathrm{z}$ raziskavo EUROSPIRE ugotovili, da urejenost dejavnikov tveganja lahko pripišejo klinični obravnavi in predpisovanju ustreznih zdravil (Kotseva, et al., 2007). Ugotovili smo, da so preiskovanci, vodeni $\mathrm{v}$ referenčni ambulanti, povečali gibalno aktivnost, napredek se je pokazal tudi pri zniževanju krvnega tlaka, holesterola in krvnega sladkorja, kar so potrdile tudi različne raziskave $\mathrm{v}$ tujini (Allen, et al., 2011, Harbman, 2014; Richardson, et al., 2014). Doprinos kakovostne obravnave s strani diplomirane medicinske sestre v RADM v Zdravstvenem domu dr. Adolfa Drolca Maribor dokazuje tudi Issakidu (2013).

Gre za prvo tovrstno raziskavo, ki je primerjala doseganje ciljnih vrednosti obravnavanih dejavnikov tveganja za razvoj srčno-žilnih bolezni po novem modelu dela ambulante družinske medicine. Pričakovali smo, da bodo zaradi intenzivnejšega spremljanja teh dejavnikov v RADM ciljne vrednosti ob kontrolni meritvi dosežene v večji meri. Menimo, da so za boljše rezultate potrebne še nekatere spremembe v organizaciji izobraževanja diplomiranih medicinskih sester, in sicer $\mathrm{v}$ smeri specializacije na tem področju. $\mathrm{Z}$ raziskavo in pridobljenimi rezultati smo uspeli delno potrditi hipotezi, na podlagi katerih lahko sklepamo, da model RADM z vključitvijo diplomirane medicinske sestre doprinese $k$ zmanjševanju dejavnikov tveganja za nastanek srčno-žilnih bolezni. Diplomirane medicinske sestre z znanjem, individualnim pristopom, zdravstvenovzgojnimi usmeritvamipacientovin rednimikontrolnimi pregledi skušajo motivirati vsakega posameznika k pravilnemu zdravemu načinu življenja in s tem zmanjševanju dejavnikov tveganja. Posredno lahko sklepamo, da diplomirana medicinska sestra s svojim pristopom pozitivno prispeva k zmanjševanju dejavnikov tveganja vsakega kontroliranega posameznika. Ustrezno strokovno usposobljena in motivirana medicinska sestra je sposobna povečati kakovost in obseg zdravstvene nege ter oskrbe pacientov in je kot taka nepogrešljiva in enakopravna sodelavka zdravniku na svojem strokovnem področju (Referenčne ambulante družinske medicine, 2012).

Glavno omejitev raziskave predstavlja vzorčenje, saj je njen vzorec omejen le na eno regijo. Podatkov tako ne moremo posplošiti, saj bi bilo $\mathrm{v}$ ta namen raziskavo treba zasnovati bolj široko. Rezultati naše raziskave sicer kažejo le na posredno uspešnost delovanja RADM, saj bi morali uspešnost delovanja RADM podkrepiti s primerjalno skupino pacientov, ki niso vodeni v RADM.

\section{Zaključek}

Raziskava je dokazala, da so pacienti, vodeni $\mathrm{v}$ RADM, pomembno zmanjšali dejavnike tveganja (krvni tlak, holesterol, visoko srčno-žilno ogroženost) za nastanek srčno-žilnih obolenj, kar bi glede na presejalni pregled in kontrolno meritev pripisali kakovostni obravnavi, ki jo omogočata model RADM in pomembna vloga diplomirane medicinske sestre, ki z znanjem, strokovno izvedeno zdravstveno vzgojo, individualnim pristopom in kakovostno obravnavo doseže, da pacienti sami pričnejo skrbeti za svoje zdravje in tako veliko prispevajo $\mathrm{k}$ zmanjševanju dejavnikov tveganja za nastanek srčno-žilnih obolenj.

Z raziskavo, ki smo jo izvedli v Zdravstvenem domu Kranj, opažamo, da se kljub kratkemu delovanju RADM na področju izvajanja kontrolnih meritev po prvem presejalnem pregledu že kažejo napredki pri zmanjševanju dejavnikov tveganja za nastanek srčnožilnih obolenj.

Vloga diplomirane medicinske sestre se je izkazala za zelo pomembno. V kratkem času svojega delovanja se RADM že lahko pohvalijo $z$ rezultati, ki so izjemnega pomena za zdravje pacientov. Z znanjem, empatijo, individualnim pristopom, rednimikontrolnimipregledi, 
zdravstveno vzgojo in upoštevanjem potreb posameznika lahko načeloma vsakega pacienta uspešno motivirajo, da prevzame odgovornost za svoje zdravje.

\section{Zahvala/Acknowledgements}

Iskrena in globoka zahvala pokojnemu somentorju, prim. prof. dr. Janku Kersniku, dr. med. spec., za vse usmeritve, pomoč, ideje, izračune, spodbude. Zahvaljujem se tudi, prim. doc. dr. Kseniji Tušek Bunc, dr. med. spec., ki je ob nenadni izgubi somentorja, brez omahovanja prevzela vlogo somentorice pri nalogi, ki je že bila v zaključni fazi./Sincere and deep gratitude to the deceased co-mentor, Chief Physician, Professor Janko Kersnik, M.D. spec., $\mathrm{PhD}$, for all his directions, help, ideas, calculations and encouragement. I also thank the Chief Physician, Assistant Professor Ksenija Tušek Bunc, M.D. spec., PhD, who did not hesitate to assume the role of co-mentor after the sudden loss of co-mentor to aid with the task, which was already in its final stage.

\section{Nasprotje interesov/Conflict of interest}

Avtorja izjavljata, da ni nasprotja interesov./The authors declare that no conflicts of interest exist.

\section{Financiranje/Funding}

Raziskava ni bila finančno podprta./The study received no funding.

\section{Etika raziskovanja/Ethical approval}

Za potrebe pregleda zdravstvenih kartotek smo pridobili dovoljenje Komisije RS za medicinsko etiko (Sklepšt. 125/04/14,6.5.2014,). Raziskavaje pripravljena v skladu z načeli Helsinško-Tokijske deklaracije (World Medical Association, 2013) in v skladu s Kodeksom etike v zdravstveni negi in oskrbi Slovenije (2014)./ For the purposes of the review of medical records, the permission from the Republic of Slovenia National Medical Ethics Committee (Resolution No. 125/04/14, 6. 5. 2014) was obtained. The study was conducted in accordance with the Helsinki-Tokyo Declaration (World Medical Association, 2013) and the Code of Ethics for Nurses and Nurse Assistants of Slovenia (2014).

\section{Prispevek avtorjev/Author contributions}

Prva avtorica članka je izvedla raziskavo, statistično analizo in napisala prvi osnutek članka. Soavtor članka je prispeval pri konceptualni zasnovi, metodologiji raziskave in pripravi rezultatov ter diskusije in pri končni potrditvi članka./The first author performed the research, statistical analysis and wrote the first draft of the paper. The co-author contributed to the study design and methodology as well as to drafting the results and discussion and final approval of the manuscript.

\section{Literatura}

Allen, J.K., Dernnison-Himmelfarb, C.R., Szanton, S.L., Bone, L., Hill, M.N., Levine, D.M., et al., 2011. Community outreach and cardiovascular health $(\mathrm{COACH})$. Tril: a randomized, controlled trial of nurse practitioner/comunity health worker cardiovascular disease risk reduction in urban comunity health centers. Circulation: Cardiovascular Quality and Outcomes, 4(6), pp. 595-602.

https://doi.org/10.1161/CIRCOUTCOMES.111.961573

PMid:21953407; PMCid:PMC3218795

Bizjak, T., 2013. Stroškovna učinkovitost prenosa aktivnosti na medicinske sestre $v$ ambulanti družinske medicine: magistrska naloga. Izola: Univerza na Primorskem, Fakulteta za vede o zdravju, pp. 36-37.

Cipot Prinčič, J., 2005. Odpravimo dejavnike tveganja za bolezni srca in ožilja. Ljubljana: Novartis, pp. 9-13.

Clark, C.E., Smith, L.F., Taylor, R.S. \& Campbell, J.L., 2010. Nurse led interventions to improve control of blood pressure in people with hypertension: systematic review and meta-analysis. British Medical Journal, 341, p. c3995

https://doi.org/10.1136/bmj.c3995

PMid:20732968; PMCid:PMC2926309

Collins, S., 2005. Explanations in consultations: the combined effectiveness of doctors andnurses communication with patients. Medical Education, 39(8), pp. 785-796. https://doi.org/10.1111/j.1365-2929.2005.02222.x PMid:16048621

Delamaire, M. \& Lafortune, G., 2010. Nurses in advanced roles: a description and evaluation of experiences in 12 developed countries. Pariz: Organisation for Economic Co-operation and Development, pp. 29-35.

Govc Eržen, J., 2004. Zdravstveno vzgojne delavnice 2002/2003. In: Z., Fras, ed. Slovenski forum za preventivo bolezni srca in ožilja 2004: zbornik prispevkov, Ljubljana, 27. marca 2004. Ljubljana: Združenje kardiolgov Slovenije, pp. 54-57.

Harbman, P., 2014. The development and testing of a nurse practitioner secondary prevention intervention for patients after a acute myocardial infarction: a prospective cohort study. International of Nursing Studies, 51(12), pp. 1542-1556.

https://doi.org/10.1016/j.ijnurstu.2014.04.004

PMid:24836930

Horrocks, S., Anderson, E. \& Salisbury, C., 2002. Systematic review of wheter nurse practitioners working in primary care can provide equal care to doctors. British Medical Journal, 324(7341), pp. 819-823.

https://doi.org/10.1136/bmj.324.7341.819

PMid:11934775; PMCid:PMC100791 
Issakidu, K., 2013. Vodenje bolnika $z$ astmo $v$ ambulanti družinske medicine: specialistična naloga. Ljubljana: Univerza v Ljubljani, Medicinska fakulteta, Katedra za družinsko medicino, p. 46.

Kodeks etike $v$ zdravstveni negi in oskrbi Slovenije in Kodeks etike za babice Slovenije, 2014. Ljubljana: Zbornica zdravstvene in babiške nege Slovenije - Zveza strokovnih društev medicinskih sester, babic in zdravstvenih tehnikov Slovenije.

Kotseva, K., Wood, D., De Backer, G., De Bacquer, D., Pyörälä, K. \& Kell, U., 2007. Cardiovascular prevention guidelines in daily practice: a comparision of EUROSPIRE I, II and III surveys in eight European countries. Lancet, 373(9667), pp. 929-940. https://doi.org/10.1016/SO140-6736(09)60330-5 PMid:19286092

Ministrstvo za zdravje Republike Slovenije, 2011. Projekt: Referenčna ambulanta. Projektna pisarna. Poročanje o kazalnikih $v$ referenčnih ambulantah za leto 2011. Ministrstvo za zdravje. Nadgradnja zdravstvenega sistema do leta 2020.

Available at: http://www.vlada.si/fileadmin/dokumenti/si/projekti/2011/ zdravstvena/NADGRADNJA ZDRAVSTVENEGA SISTEMA DO LETA 2020 pdf 160211.pdf [12.9.2013].

Paniagua, H., 2011. Advanced nurse practitioners and GPs: what is the difference? Practice nursing, 22(7), pp. 386-388. Available at: http://www.magonlinelibrary.com/doi/abs/10.12968/ pnur.2011.22.7.383 [17. 11.2016]

Pečelin, S. \& Sočan, M., 2015. Referenčne ambulante: izkušnje diplomiranih medicinskih sester. Obzornik zdravstvene nege, 50(2), pp. 157-162.

Available at: http://www.obzornikzdravstvenenege.si/2016.50.2.157 [17. 11. 2016].

Petek Šter, M. \& Šter, B., 2014. Pomen izobraževanja diplomiranih medicinskih sester $\mathrm{v}$ referenčnih ambulantah: primer arterijske hipertenzije. Obzornik zdravstvene nege, 49(1), pp. 52-59.

Available at: http://www.obzornikzdravstvenenege.si/2015.49.1.52 [17. 11. 2016].

Redsell, A.S. \& Cheater F.M., 2008. Nurse's roles in primary care: developments and future prospects. Quality in Primary care, 16(2), pp. 69-71. Available at:

http://primarycare.imedpub.com/nurses-roles-in-primary-caredevelopments-and-future-prospects.pdf [17. 11. 2016].

PMid:1870008
Referenčne ambulante družinske medicine, 2012. Projekt ministrstva za zdravje. Available at:

http://www.referencna-ambulanta.si/ [2. 10. 2013].

Richardson, G.C., Derouin, A.L., Vorderstrasse, A.A., Hipkens, J., \& Thompson, J.A., 2014. Nurse practitioner management of tipe 2 diabetes. The Permanente Journal, 18(2), pp. e134-e140. https://doi.org/10.7812/TPP/13-108

PMid:24867560; PMCid:PMC4022572

Shum, C., Humphreys, A., Wheeler, D., Cochrane, M.A., Skoda, S., \& Clement, S., 2000. Nurse management of patients with minor illnesses in general practice: multicentre, randomised controlled trial. British Medical Journal, 320(7241), pp. 1038-1043.

https://doi.org/10.1136/bmj.320.7241.1038

PMid:10764365; PMCid:PMC27346

World Medical Association, 2013. World Medical Association Declaration of Helsinki: ethical principles for medical research involving human subjects. Journal of the American Medical Association, 310(20), pp. 2191-2194.

Avaliable at: http://www.wma.net/en/20activities/10ethics/10h elsinki/DoH-Oct2013-JAMA.pdf [1.9.2016].

World Health Organization, 2008. The World Health Report primary Health Care (Now More Than Ever) Available at: http://www.who.int/whr/2008/en/index.html [10. 5. 2015].

Šic, A., 2009. Sodobno življenje in nevarnosti za srce in ožilje: diplomsko delo. Maribor: Univerza v Mariboru, Fakulteta za zdravstvene vede, pp. 23-28.

Štemberger Kolnik, T. \& Klemenc, D., 2010. Stroka zdravstvene nege ob Mednarodnem dnevu medicinskih sester zagotavlja varnost in uvaja novosti. In: T. Štemberger Kolnik, \& S. Majcen Dvoršak, eds. Medicinske sestre zagotavljamo varnost in uvajamo novosti pri obravnavi pacientov s kroničnimi obolenji. 12. simpozij zdravstvene in babiške nege Slovenije; 2010, maj 5-6, Portorož. Ljubljana: Zbornica zdravstvene in babiške nege Slovenije - Zveza strokovnih društev medicinskih sester, zdravstvenih tehnikov in babic; Koper: Društvo medicinskih sester, zdravstvenih tehnikov in babic, pp. 5-6.

Venning, P., Durie, A., Roland, M., Robets, C., \& Leese, B., 2000. Randomised controlled trial comparing coast effectiveness of general practitioners and nurse practitioners in primary care. British Medical Journal, 320(7241), pp. 1048-1053.

https://doi.org/10.1136/bmj.320.7241.1048

PMid:10764367; PMCid:PMC27348

Citirajte kot/Cite as:

Terbovc, A. \& Gomišček, B., 2017. Obvladovanje dejavnikov tveganja za nastanek srčno-žilnih bolezni v referenčni ambulanti družinske medicine. Obzornik zdravstvene nege, 51(1) pp. 34-41. https://dx.doi.org/10.14528/snr.2017.51.1.100 